\title{
Effectiveness of Learning Centre (LC) to Improve Learners' Indonesian Competence
}

\author{
I Made Rai Jaya Widanta ${ }^{1}$ \\ Mechanical Engineering Department \\ Politeknik Negeri Bali \\ Bali, Indonesia \\ ${ }^{1}$ maderaijayawidanta@pnb.ac.id \\ Anak Agung Raka Sitawati \\ Business Administration Department \\ Politeknik Negeri Bali \\ Bali, Indonesia
}

\author{
Putu Dyah Hudiananingsih \\ Accounting Department \\ Politeknik Negeri Bali \\ Bali, Indonesia
}

\author{
Gede Ginaya \\ Tourism Department \\ Politeknik Negeri Bali \\ Bali-Indonesia
}

\begin{abstract}
This study aimed at investigating effectiveness of Learning Centre (LC) to improve Darmasiswa students' Indonesian competence. $\mathrm{LC}$ was designed as a site where students were able to learn grammar of Indonesian autonomously. It was developed as students found it difficult to study grammar in cooperation with language skills in the class. Thus, they required an exclusive and discrete grammar lesson. The research participants involved nine foreign students of Darmasiswa program. The participants were trained on $\mathrm{LC}$ program and given chance to study grammar individually. To measure its effectiveness, two tests were applied, pre-test and post-test. Treatment in LC was done ten times. Result of both tests were compared and analyzed. The test and LC materials were developed and validated by an expert judge before their use. The materials were taken from books used for formal class lesson. The result of measurement fostered that $\mathrm{LC}$ with self-directed learning was effective to improve learners' Indonesian language competence. This indicates that autonomous learning is worth practicing to promote students' noticing.
\end{abstract}

Keywords-learning Centre (LC); effectiveness; self-directed; learning; indonesian competence

\section{INTRODUCTION}

Grammar, the rule based on which speakers have a track to step on, is one of competences language learners have to achieve as a goal [1]. To make more effective, grammatical competence shall be supported with two other competences, they are sociolinguistic and strategic competence. However, grammar still plays an important, or even the most dominant, role as language will not work without its existence. In the more common world, grammar includes and refers to and associated with some technical terms, such as competence, pragmalinguistics, langue, and accuracy [2]. Those aspects are parts of communicative competence that some linguists try to breakdown [3-6]. Grammar can be learned through using the language itself in communication, learning it explicitly or implicitly, or learning it in the more discrete way. Of a number of learning models proposed by experts in field of education, self-directed learning is attractive to some people for its characters.

There have been a number of researches investigating how self-directed learning (SDL) is implemented in pedagogical intervention. Internet-based SDL, for instance, was implemented to recognize whether or not it was effective I America [7]. Hiemstra interviewed and distributed questionnaire to respondents to trace to what extent internet benefit learners' learning. The research result responded that internet was proven to be visible and effective to help leaners of the village access information widely. The learners were able to make changes for their lives. The remarkable achieved outcome implies that SDL is very worth implementing since it made a learning meaningful. This research is in line with the work carried out by [8-9] that SDL was able to encourage learners to solve problems to get a successful end. Their research involved respondents above 50 years old who were prepared to do autonomous learning [10]. It's endeavors successfully found that autodidact and autonomous learning could build learners' confidence that they are committed to developing their potency. The adult-suited learning model combines three important aspects, such motivation, selfmanagement, and self- monitoring [11]. Focusing on end product, this learning model was effective to build learners' characters which prioritizes and energizes personal character, like self-willingness, self-controlling, as well as self-directed learning in a natural situation [12]. In addition, it was able to trigger learners' critical thinking to construct meaning [13].

Apart from the English pedagogical endeavor, Indonesian language instruction investigation was also carried out. It was trying to make use a number of learning models to find out and develop a more effective model. [14] developed and studied a 
model that suited the Indonesian language as a foreign language in the program of Teaching Indonesian as Foreign Language di Australia. The study successfully drawn an end that task-based learning (TBL) is the most effective to apply as it relied on communicative language teaching (CLT) [15-16]. The conclusion was based on the fact that the Indonesia language learning goal is to improve learners' Indonesian language competence particularly that of speaking. The Indonesian instruction using self-regulated learning (SRL) was carried out by [17]. The study investigated whether or not SRL is visible to implement in the instruction. The work eventually proven that SRL was supportive to the Indonesian language pedagogy. The basic assumption drawn from the research was that the model is going to be more effective if it is supported with learners' self-conviction and their ability to empower their potency. This spirit is in line with the end finding of the work done by [1819], [21]. Moreover, the learning was said to be more successful if it is supported with some other important aspects to embody learning achievement, such as self-efficacy, and volition [21]. Other Indonesian language instruction for adult tutorial model done by [22] in purpose to prove the efficiency the model fostered. Involving a pair of students who were faced with one tutor in order for them to be able to learn as much Indonesian language as possible. This model was also found effective as it was initiated by recognizing and identifying learners' weakness. The use of technology in the Indonesian instruction was projected by [23]. It was done by implementing information communication technology (ICT) to teach Indonesian. Learning materials, exercise, and evaluation tool were designed and integrated using ICT. The model was found effective for the Indonesian learning. Finally, [24] designed Indonesian learning materials using model designed by [25] comprising dialog, listening, reading, writing, and analysis of sentences. It was found effective as it was combined with immersion program.

There have been a number of studies centering on investigating the effectiveness of SDL model in language learning. However, none has fostered to what extent such model is effective to the Indonesian language learning. This research is undertaken in purpose to recognize whether or not it is visible for foreign learners of Indonesian language in Indonesian.

This present research is focused on designing a learning center (LC) for foreign students to learn Indonesian language. It is designed with SDL and designed based on [25]'s concept. It is closely associated with the work of [6] LC development for learning TOEIC (Test of English for International Communication) and [7]'s (2015) development of LC for learning TOEFL (Test of English as a Foreign Language). However, these two studies focused on English instruction particularly that of English standard tests whose special aim is at learners' academic achievement. Conversely, this present study is focusing on how foreign learners' of Indonesian language master grammatical points through SDL at LC.

Self-directed learning is the adult learning strategy. The strategy promotes that adult learners are able to learn while having other duties or position, such as being involved in family, work, or other work [28-33]. Adult learners are those above 24 years old who also play different role, such as farther, worker, or others [33]. As they are not focused on doing the learning, like school children, adult learners should develop their other supporting skills, such as finding and evaluating information, identifying information, organizing information, writing report and paper, managing time, remembering what they have learned, using problem solving system, and monitoring one's own learning or meta-cognition [34]. Apart from those skills, [12] and [35] recommend that learners have to do a group-based collaboration. They propose some strategies to support one's goal as successful SDL learners, such as internship, online discussion, group learning. Others suggest that SDL can be successfully realized by implementing self-regulated learning (SRL) [36].

There is no clear difference between SDL and SRL. They both have the same characteristic. Like SDL, SRL can be achieved with a learning strategy called meta-cognitive model with some cyclical phases: assessment, evaluate, plan, apply, and reflect [37]. In line with this, there are three stages to reach the remarkable end of SRL, such as forethought \& planning, performance-monitoring, performance-reflecting [20] and [30]. As they are proven to be successful and effective in some context, SDL or SRL should be maintained in their implementation. Their sustainability depends upon learners' motivation [38-39], [20]. It is worth energizing that these learning models suit the learning in higher education particularly for vocational students. Thus Jossberger, et al [36] suggest that students at vocational college should acquire skills of SDL and SRL as they have to prepare themselves before, they go to workplaces.

Learning center (LC) is the place where the learning of Indonesian language by foreign students done individually. They undertake the learning on their own pursuant to the standard operating procedure (SOP) prepared for LC. Almost entire learning activities, such as setting the goal, deciding what materials or module the learners will work out, working out the exercise and the practice test, and checking their work using the answer key are done autonomously. Instructors or staff of LC are assigned only to help learners provide the test books, answer sheet, the answer key, as well as noting the mark learners acquire into the credit point card.

\section{METHOD}

This research was in purpose to design LC model with SDL for foreign students learning Indonesian language. It is focused on developing a suitable model for learning grammar point to ease their Indonesian language mastery as grammar learning is found complex which needs special endeavor. There were a group nine foreign students involved in the research. They are enrolled as "Darmasiswa" students, the Indonesian scholarship program for foreign students who learn Indonesian language and culture. Their learning period last 10 months, starting from September 2017 until July 2018. It is important to note that the participant have not learned Indonesian or lived in Indonesia prior to their course in Indonesia. The participants were given 
pre-test prior to their learning in LC in order to recognize their basic level of ability.

The treatment given to the participant involved Indonesian grammar materials designed in form of module. There materials were prepared to facilitate their SDL activities at LC. There were ten modules prepared for the learning, each of which comprises of Indonesian grammar topics, explanation of grammar points and practice test. The topics were taken from Indonesian subject learning module used for the in-the class learning. Each topic was chosen and developed to make grammar-discrete learning module for LC. Materials in the module include explanation, information about the use the grammar point, example on how it is used in the sentence. As the learners are from very basic level, the information given in the modules is also written in English language to ease them to comprehend the materials. Each module is completed with answer key saved apart from the module. After they learn and work out a certain practice test of a certain module, they are allowed to check their work using the answer key. Students were trying to work out ten-session learning individually. Each student spent around forty five minutes until one hour to finish one module. As they are not bound with fix schedule during the ten-session SDL activity, they could freely come to LC to do the learning on their own. The staff of the LC had to be ready anytime to serve the participants' learning. The staff was assigned to prepare test book, answer sheet, answer key, and record their mark in the credit point card upon their learning. Participants participated in the LC learned at different time pursuant to their mood and opportunity. This was designed purposefully in order to avoid their working out the task in pair or group mutually. However, they were required to complete the ten sessions before the post-test administered.

The test (for pre-test and post-test) consists of all grammar materials compiled in Indonesian learning book used in the class. This test was used to measure their basic competence and their competence upon the treatment. Prior to its use as a valid testing tool, the test was validated by an expert judge, in term of its content, design, number of questions it contains, its level of difficulty, as well as its scope. The results of pre-test and post-test were noted, compared and analyzed. There are forty questions the test comprises. The number of the questions were determined on the basis of the materials of the Indonesian learning book. The scoring rubric comprises of forty scores, ranging from one to forty. Scoring system applies converting system. The forty (the highest score) is converted into 100 and the 1 (the lowest score) is converted into 2.5. To get the converted number, each correct number of answers is multiplied by ten and is divided by four (e.g. $40 \times 10: 4=100)$.

TABLE I. SCORING RUBRIC

\begin{tabular}{|c|c|c|c|c|c|}
\hline $\begin{array}{c}\text { Raw } \\
\text { Score }\end{array}$ & Conversion & $\begin{array}{c}\text { Raw } \\
\text { Score }\end{array}$ & Conversion & $\begin{array}{c}\text { Raw } \\
\text { Score }\end{array}$ & Conversion \\
\hline 40 & 100 & 27 & 67,5 & 14 & 35 \\
\hline 39 & 97,5 & 26 & 65 & 13 & 32,5 \\
\hline 38 & 95 & 25 & 62,5 & 12 & 30 \\
\hline 37 & 92,5 & 24 & 60 & 11 & 27,5 \\
\hline 36 & 90 & 23 & 57,5 & 10 & 25 \\
\hline
\end{tabular}

\begin{tabular}{|c|c|c|c|c|c|}
\hline $\begin{array}{c}\text { Raw } \\
\text { Score }\end{array}$ & Conversion & $\begin{array}{c}\text { Raw } \\
\text { Score }\end{array}$ & Conversion & $\begin{array}{c}\text { Raw } \\
\text { Score }\end{array}$ & Conversion \\
\hline 35 & 87,5 & 22 & 55 & 9 & 22,5 \\
\hline 34 & 85 & 21 & 52,5 & 8 & 20 \\
\hline 33 & 82,5 & 20 & 50 & 7 & 17,5 \\
\hline 32 & 80 & 19 & 47,5 & 6 & 15 \\
\hline 31 & 77,5 & 18 & 45 & 5 & 12,5 \\
\hline 30 & 75 & 17 & 42,5 & 4 & 10 \\
\hline 29 & 72,5 & 16 & 40 & 3 & 7,5 \\
\hline 28 & 70 & 15 & 37,5 & 2 & 5 \\
\hline & & & & 1 & 2,5 \\
\hline
\end{tabular}

\section{RESULT AND DISCUSSION}

There are 9 participants participating in this research. All of them are foreign students who take Darmasiswa program, i.e. one-year-Indonesian and culture course for foreigner funded by the government of Indonesia. The participants were involved in the learning of Indonesian at LC with SDL approach. Prior and up on the learning as a treatment, they were given tests (pre-test and post-test). Result of both tests are showed beneath. These test scores were the results of conversion using the scoring rubric specially designed for the model.

TABLE II. Participant Score of Pre-Test and Post-Test

\begin{tabular}{|c|c|c|c|c|}
\hline Participant & $\begin{array}{c}\text { Converted } \\
\text { Score } \\
\text { (Pre-Test) }\end{array}$ & $\begin{array}{c}\text { Converted } \\
\text { Score } \\
\text { (Pre-Test) }\end{array}$ & $\begin{array}{c}\text { Point of } \\
\text { Increase }\end{array}$ & $\begin{array}{c}\text { Increase } \\
(\%)\end{array}$ \\
\hline 1 & 55.0 & 65 & 10.0 & 18 \\
\hline 2 & 67.5 & 75 & 7.5 & 11 \\
\hline 3 & 57.5 & 67 & 9.5 & 16.5 \\
\hline 4 & 40.0 & 60 & 20.0 & 50 \\
\hline 5 & 57.5 & 68 & 10.5 & 18.2 \\
\hline 6 & 57.5 & 67 & 9.5 & 16.5 \\
\hline 7 & 67.5 & 75 & 7.5 & 11 \\
\hline 8 & 65.0 & 74 & 9.0 & 13.8 \\
\hline 9 & 65.0 & 73 & 8.0 & 10.9 \\
\hline Total & 532.5 & 624 & 91.5 & 165.9 \\
\hline
\end{tabular}

As can be clearly seen, the scores of the participants in pretest was more heterogenic than that of post-test. Those scores were mostly lower average. More participants (5 people) got lower than average score, and 4 participant obtained above average score. The highest scored of pre-test was 67.5, obtained by two participants (participant 2 and 7). This score is considered above fair as more than half of the total questions in the test were answered correctly. Another above average score was 65.0, only two and half point below the highest score. It was obtained by two participants (participant 8 and 9). The lowest score was 40.0 obtained by only one participant (participant 4). This score a bit drastically declined than the other scores. The other lower average scores are 57.5 and 55.0. There were two participants pursued 57.5 and only one participant obtained 55.0. The total score of pre-test was 532.5. This score is still considered below average. There were more participants incompetent grammatically than these of competent.

The condition changed up on the treatment. It can be observed obviously that the participant showed better competence in grammatical aspect. It is proven by the fact that their total score was 624.0. It increased 92 points from their pre- 
test result. This achievement increased $17.2 \%$. This improvement is considered fair. The highest score (75.0) was obtained by two participants (participant 2 and 7). The highest score was pursued by the same participant whose pre-test score was the highest. The second highest score was obtained by one participant (participant number 8). The participant number 9 who got the same score with participant number 8 in pre-test showed a bit declined performance in post-test with score 73.0. The spectacular improvement of performance was showed by the participant number 4 whose score was the lowest (40.0) in pre-test. He performed a lot better in the post-test with score 60.0. He was able to show the highest improvement of all. The forth and the fifth highest scores were 68.0 and 67.0 respectively. These scores are not different significantly. The sixth score was 65.0 obtained by participant 1 . All participants pursued above average score. The trend significantly raised from the pre-test as all participants' score was above average and some of them even pursued 'good' mark. The results show that $55.5 \%$ of the participants obtained above average score in pre-test and $100 \%$ participant obtained score above average.

Increase in the point of each participant from pre-test to post-test can also be seen obviously that, the highest increase in point was 20 point. This remarkable increase was fostered by the participant whose scores of pre-test and post-test were the lowest. This case has strongly proven that SDL showed an effectiveness. The second highest points were 10.5 and 10 obtained by two participants. The lowest points were 8 and 7.5. However, points 9 and 9.5 were obtained by three participants. Similarly, the positive trend also displayed by the increase of each participant by percentage. It can be clearly seen that the highest increase in percent was $50 \%$ fostered by the participant whose score was the lowest in pre-test and post-test. The second highest percentages were 18.2 and 18.0 obtained by two participants. The lowest percentage achieved were 10.9 and 10.0 of three participants. The higher scores from three participants were 13.0 (by one participants) and 16.5 (by two participants).

A part from the test result, an attention should also be given to the assessment tool in order for students to be able to anticipate the learning. By overviewing the test, in term of which aspects of the test were found challenging. Of the two sections of the test, 'written expression' section seems to be far challenging than 'structure' for the participants. It is driven by the type of sentences that 'written expression' promote far more complex and complicated sentence. Participants were not familiar with finding an incorrect part of sentence. There a number of points of grammar which the participants have been familiar with. The endeavor has to be put in attempt to recognize the participants' point of difficulty and which parts of the grammar shall be given an emphasis in the modules. The first point they found confusing was formation of 'noun phrase' using the word 'saya'. In its use, they often switch its position to be 'saya hobi' to express 'my hobby'. The use of affixes also matter the participants. Most of them failed to comprehend and use compound words with prefixes, for instance verb with prefix 'ber-'. In addition to this, the use of question word 'berapa' was puzzling for them, particularly to use 'berapa lama, berapa jauh, berapa banyak, berapa orang, berapa harganya, berapa sering'. Collocation seemed to bother them, as they failed to decide which words suit other words, for instance 'menyatakan or mengucapkan' to precede the word 'selamat ulang tahun' and the like. The other hindrance was related to the use of possessive '-nya' being compared to 'dia'. They tended to use subject 'dia' to expresses and change possessive marker '-nya'. Lastly, they mostly failed to differentiate and use negative marker 'bukan' and 'tidak'.

In spite SDL approach which does not foster teacher-led pedagogical intervention, LC also provides occasion where there is a teacher-student interaction. Even though not very intensive, it is done purposefully to provide learners with feedback they require for final information. To regulate the learning, LC provide a learning syntax based on which the learning activities in LC is conditioned. The learning syntax consists of three main stages, they are 'before learning', 'on the learning', and 'closing'. On the 'before learning' learners do not do any SDL yet, as the occasion of about 5 minutes is used for administrative affairs. On the learning activity is the most stage where learners are given feedback on, particularly, the mistakes learners have made in case of a small number of mistakes they made or their mark achieved is eligible to be recorded at the credit point card. If it is not, and they have to repeat to work out the exercise, feedback will be given afterward. The 'on-thelearning' session is essential as learners have a wide chance to investigate grammar points by reading, comprehending and doing exercises on the module. In addition, the modules are very helpful as they are written both in Indonesia and English language.

\section{CONCLUSION}

The scene above showed an insightful achievement of learners by the help of LC with SDL approach. The model was found successful to help learners improve their language skill especially that of grammar or form. It helped adult learners to effectively achieve learning goals. Learners' perception also fostered positively that the model fit their autonomous learning style. However, endeavor should necessarily be taken to learners' goal of speaking competence. For this purpose, a learning which focuses on improving learners' braveness in using the language in verbal interaction is needed. Thus, further research has to be undertaken to investigate and find effective model to improve learners' Indonesia language speaking competence.

\section{ACKNOWLEDGMENT}

The author would like to thank Directorate Research and Social Service, Ministry of Research, Technology, and Higher Education for their financial support that this research was successfully undertaken.

\section{REFERENCES}

[1] I.M.R.J. Widanta, "Self-Directed Learning (SDL)-Based Learning Center (LC): a Strategy to Improve Students' TOEFL Score,” Int. J. Res. Soc. Sci., vol. 6, no. 2, pp. 51-58, 2018. 
[2] I.M.R.J. Widanta, "Pengembangkan learning center (LC) dengan model pembelajaran mandiri bahasa Inggris berbasis TOEFL: laporan penelitian hibah bersaing dibiaya oleh DP2M Dikti," unpublished.

[3] N. Chomsky, Aspect of the Theory of Syntax, Massachusetts: Massachusetts Institute of Technology, 1964, pp. 203-217.

[4] G. Leech, Principles of pragmatics, London: Longman, 1983, pp. 175189.

[5] F. Saussure, Saussure. Jakarta: Pusat Pembinaan dan Pengembangan Bahasa, Departemen Pendidikan dan Kebudayaan, 1996.

[6] J.C. Richards, Communicative Language Teaching Today. New York: Cambridge University Press, 2006.

[7] A. Bandura, Self-Efficacy: The exercise of control. New York: W. H. Freeman and Company. 1997.

[8] R. Hiemstra, "Is the Internet Changing Self-Directed Laerning? Rural Users Period Some Answers,” Int. J. Self-Direct. Learn., vol. 3, no. 2, pp. 45-60, 2006.

[9] M.M. Mok and C.H. Lung, "Developing SDL in Student Teachers," Int. J. Self-Direct. Learn., vol 2, no. 1, pp. 18-39, 2005.

[10] S.K. Wilson, "Self-Directed Learner Concept of Self as Learner Congrous," Int. J. Self-Direct. Learn., vol. 3, no. 2, pp. 1-13, 2006.

[11] D.R. Garrison, "Self-Directed Learning: Toward a Comprehensive Model," Adult Educ. Quarterly, vol. 48, pp. 18-33, 1997.

[12] P.C. Candy, Self-Direction for Lifelong Learning: A Comprehensive Guide to Theory and Practice, San Francisco: Jossey-Bass, 1991, pp. 208219.

[13] S.L. Stockdale, "Development of an Instrument to Measure SelfDirectedness," unpublished.

[14] J.E. Read, "Innovation in Indonesian Language Teaching; an Evalution of TIFL Tertiary Curriculum Materials, unpublished.

[15] D. Nunan, Designing Task for Communicative Classroom, Cambridge: Cambridge University Press, 1993, pp. 87-95.

[16] J.C. Richards and T.S. Rodgers. 1986. Approach and Methods in Language Teaching. Cambridge University Press.

[17] S. Chiakrawati, Pembelajaran Bahasa Indonesia untuk Penutur Asing melalui Pendekatan SRL, unpublished.

[18] A. Bandura, Self-Efficacy: The Exercise of Control. NewYork: W. H. Freeman and Company, 1997.

[19] D.H. Schunk, "Goals and Self-Evaluative Influences during Children's Cognitive Skill Learning,” American Educ. Res. J., vol. 33, pp. 359-382, 1996.

[20] B.J. Zimmerman, "Sociocultural Influences and Students' Development of Academic Self-Regulation: A Social Cognitive Perspective," in Big Theories Revisited, D. M. Mc.Inerney and V. Etten's, Eds, pp.139-164, Information Age, Green Wich, 2004.

[21] C. Wolters, "Self-Regulated Learning and College Students' Regulation of Motivation,” J. Educ. Psychol., vol. 38, no. 189-205. 1998.
[22] H.S. Widodo, Pembelajaran BIPA dengan Model Tutorial, 1994.

[23] M.B. Siroj, "Pengembangan Model Integratif Bahan Ajar Bahasa Indonesia Ranah Sosial Budaya Berbasis ICT Bagi Penutur Asing Tingkat Menengah,” J. Pendidik. dan Sastra Indonesia, vol.1, 2015.

[24] I. Suyatno,"Pengembangan Bahan Ajar Bahasa Indonesia untuk BIPA," Wacana, vol. 9, no. 1, pp. 62-78, 2007.

[25] W. Dick and L. Carey, The Systematic Design of Instruction, Second Edition. Illinois: Scott, Foresman and Company, 1990.

[26] K.D.C. Putra, Pengembangan Model Pembelajaran Mandiri Bahasa Inggris Berorientasi TOEFL. Laporan Penelitian Politeknik Negeri Bali, unpublished.

[27] I.M.R.J. Widanta, Pengembangkan Learning Center (LC) dengan Model Pembelajaran Mandiri Bahasa Inggris Berbasis TOEFL: Laporan Penelitian Hibah Bersaing Dibiaya oleh DP2M Dikti, unpublished.

[28] R.S. Caffarella, "Self-Directed Learning. New Directions for Adult and Continuing Education,” pp. 25-35, 1992.

[29] M. S. Knowles, Self-Directed Learning, New York: Association, Press. 1975.

[30] M.S. Knowles, E.F. Holton, and R.A. Swanson, The Adult Learners: The Definitive Classic in Adult Education and Human Resources Development, Elsevier: Burlingston, MA, 2005.

[31] S.B. Merriam, “Andragogy and Self-Directed Learning, New Direction for Adult and Continuing Education," vol. 89, pp. 3-14, 2001.

[32] S.B. Merriam, and R. S. Caffarella, Learning in Adulthood, Jossey-Bass: San Fransisco, 1999.

[33] H. Khiat, "Measuring Self-Directed Learning: A Diagnostic Tool for Adult Learners," J. University Teach. Learn. Prac., vol. 2, no. 2, 2015.

[34] T. Doyle, Helping Students Learn in a Learning-Center Environment. A Guide to Faciliting Learning in Higher Education, Stylus Sterling VA, 2008.

[35] A.B. Knox, Helping Adult Learn, Jossey-Bass: San Fransisco. 2009.

[36] H. Jossberger, S. Brand-Gruwel, H. Boshuizen, and V. D. Margje "The Challenge of Self-Directed and Self-Regulated Learning in Vocational Education: a Theoretical analysis and Synthesis of Requirements," J. Vocat. Educ. and Training, vol. 62, no. 4, pp. 415- 440, 2010.

[37] S. Anbrose, M. Bridges, DiPieto, M. Lovett, and M. Norman, How learning Works: Seven Research-Based Principles for Students' Teaching, Jossey-Bass, SF, 2010.

[38] P. Pintrich, "Multiple Goals, Multiple Pathways: The Role of Goal Orientation in Learning and Achievement," J. Educ. Psychol., vol. 92, pp. 544-555, 2004.

[39] M.T. Wang and Holcombe, “Adolescent's Perception of School Environment, Engagement, and Academic Achievement in Middle School," American Educ. Res. J., vol. 47, no. 3, pp. 633-662, 2010 